\title{
Epitope-optimization creates highly immunogenic alpha fetoprotein antigen to break immune tolerance and potently activates CD8 T cells to prevents autochthonous hepatocellular carcinoma
}

\author{
Yuan Hong ${ }^{1}$, Yibing Peng ${ }^{1}$, Sheng Z Guo ${ }^{3}$, Junfeng Pang ${ }^{1}$, Jose Guevara-patino², David H Munn', \\ Nahid Mivechi', David Bartlett ${ }^{3}$, Yukai He ${ }^{1 *}$
}

From Society for Immunotherapy of Cancer 28th Annual Meeting

National Harbor, MD, USA. 8-10 November 2013

In this study, we investigated whether mouse alpha fetoprotein (mAFP), the shared self/tumor antigen of hepatocellular carcinoma (HCC), could be rationally engineered to create effective vaccine to break tolerance and potently activate CD8 T cells to prevent clinically-relevant carcinogen-induced autochthonous HCC. We found that the computer-guided epitope-optimization created optimized opt-mAFP and that immunization with lentivector (lv) expressing opt-mAFP, but not wt-mAFP, potently activated $\mathrm{CD} 8$ cells specific for three novel $\mathrm{H}-2 \mathrm{~b}$ restricted CD8 epitopes, which cross-recognized wt-mAFP epitopes naturally processed and presented by wt-mAFP+ tumor cells. Immunization with opt-mAFP-lv, but not wt-mAFPlv, completely protected mice from wt-mAFP+ tumor challenge and effectively prevented carcinogen-induced autochthonous HCC. Prime-boost with opt-mAFP-lv and vaccinia vector opt-mAFP-vv significantly increased the wt-mAFP-specific CD8 $\mathrm{T}$ cells that were highly responsive to emerging $\mathrm{HCC}$ tumor cells in the liver, enhancing prevention of autochthonous HCC. Our data demonstrate that epitope-optimization creates immunogenic opt-mAFP that is able to break tolerance and activate potent CD8 responses, which can cross-recognize wt-mAFP peptides, but also recognize and kill mAFP+ tumor cells. Our study provides a practical roadmap to develop effective human vaccines that should have a better chance of success than the current human HCC vaccines based on native wt-AFP.

${ }^{1}$ Cancer Center, Georgia Regents University, Augusta, GA, USA

Full list of author information is available at the end of the article

\section{Authors' details}

${ }^{1}$ Cancer Center, Georgia Regents University, Augusta, GA, USA. ${ }^{2}$ Surgery, Loyola University, Chicago, IL, USA. 'Surgery, University of Pittsburgh, Pittsburgh, PA, USA.

Published: 7 November 2013

doi:10.1186/2051-1426-1-S1-P216

Cite this article as: Hong et al:: Epitope-optimization creates highly immunogenic alpha fetoprotein antigen to break immune tolerance and potently activates CD8 T cells to prevents autochthonous hepatocellular carcinoma. Journal for ImmunoTherapy of Cancer 2013 1(Suppl 1):P216.

Submit your next manuscript to BioMed Central and take full advantage of:

- Convenient online submission

- Thorough peer review

- No space constraints or color figure charges

- Immediate publication on acceptance

- Inclusion in PubMed, CAS, Scopus and Google Scholar

- Research which is freely available for redistribution 